\title{
Seasonal Incidence of Major Sucking Insect Pests of Groundnut in Relation to Weather Parameters of Semi-Arid Region of India
}

\author{
Sunil Gocher ${ }^{1}$ and Sarfraz Ahmad ${ }^{2 *}$ \\ ${ }^{1}$ Department of Entomology, S.K.N. College of Agriculture, S.K.N. Agriculture University, \\ Jobner-303 329, Rajasthan, India \\ ${ }^{2}$ Department of Plant Breeding and Genetics, S.K.N. College of Agriculture, S.K.N. \\ Agriculture University, Jobner-303 329, Rajasthan, India
}

*Corresponding author

Keywords

Aphid, Groundnut, Leafhopper, Natural enemies, Seasonal incidence, Weather parameter

Article Info

Accepted:

10 July 2019

Available Online:

10 August 2019

\section{A B S T R A C T}

The study had been carried out in the semi-arid region of India at Agronomy farm, S.K.N. College of Agriculture, Jobner (Rajasthan) during Kharif 2018. The insect pests, aphid (Aphis craccivora Koch) and leafhopper (Empoasca kerri Pruthi) were observed as major sucking insect pests infesting on groundnut crop. The aphid and leafhopper population commenced in the last week of July and reached to its peak in the second week of September, when the maximum temperature, minimum temperature, relative humidity and rainfall were $30.0{ }^{\circ} \mathrm{C}, 21.0{ }^{\circ} \mathrm{C}, 78 \%$ and $1.6 \mathrm{~mm}$, respectively. The population of aphid and leafhopper showed significant negative correlation with maximum temperature and significant positive correlation with relative humidity. The population of predators and maggot of Syrphid fly were appeared in the first week of August and reached to maximum in the third week of September. The populations of both the predators were significant positively correlated with aphid and leafhopper populations. Both predators had non-significant correlation with weather parameters except Lady bird beetle which showed significant positive correlation with relative humidity.

\section{Introduction}

Groundnut (Arachis hypogaea L.) is an annual legume crop also known as peanut, grown in the semi-arid tropics and is the principle oilseed crop in India (Kandakoor et al., 2012). Groundnut oil is considered as stable and nutritive as it contains right proportion of
Oleic and Linoleic acids (Mathur and Khan, 1997). The seed contains upto50 per cent of a non-drying oil, 40-50 per cent fat, 20-50 per cent protein and 10-20 per cent carbohydrate (Mehta, 2002). More than 100 species of insect and mites are known to attack groundnut (Nandagopal, 1992). Among the various insect pests attacking this crop, 
leafhopper (Empoasca kerri Pruthi) and aphid (Aphis craccivora Koch), causes extensive damage and found to be serious on groundnut crop (Mer et al., 2016). The indiscriminate and injudicious use of synthetic pesticides have lead to pest build up and cause an imbalance of natural enemies, resulting into problems of pest resurgence and secondary pest out breaks progressively (Ahir et al., 2017). The knowledge of incidence of sucking pest viz aphid (Aphis craccivora Koch) and leafhopper (Empoasca kerri Pruthi) and their natural enemies viz Lady bird beetle (Coccinella septempunctata L.) and Syrphid fly (Syrphid spp.) at different growth stages of groundnut crop will be helpful in evolving proper management schedule. The present study will provide the necessary information to understand the dynamics of the population buildup of sucking insect pest and natural enemies at semi-arid region of India.

\section{Materials and Methods}

The present investigation was conducted at the Agronomy farm of S.K.N. College of Agriculture (S.K.N. Agriculture University, Jobner, Rajasthan) during Kharif, 2018.

The climate of this region is typically semiarid which is characterized by extremes of temperature both in summer and winter with low rainfall and moderate humidity. Variety RG 382 (Source: Rajasthan Agriculture Research Institute, Durgapura, Jaipur) was used in the study and sown on in five plots. The plot size was $2.4 \mathrm{~m} \times 3.0 \mathrm{~m}$ with row to row and plant to plant distance of $40 \mathrm{~cm} \times 15$ $\mathrm{cm}$, respectively. The population of major sucking insect's pest's viz., leafhopper and aphid were recorded at weekly interval early in morning hours from initiation of pests till harvesting of the crop. The aphid and leafhopper population were counted on three leaves per plant from the five selected and tagged plants form each plot as per method suggested by Satpathy (1973). The population of natural enemies viz., lady bird beetle and syrphid flies were also recorded on the same selected five plants. For statistical analysis OPSTATE software was used which is available online at HAU, Hisar web site.

\section{Results and Discussion}

Mean population of Aphid and Leafhopper along with natural enemies Lady bird beetle and Syrphid fly has been presented in Table 1 and graphically represented in Figure 1 . Correlation coefficient of sucking insect pests with weather parameters and their natural enemies of groundnut depicted in Table 2.

\section{Aphid (Aphis craccivora Koch) and Leafhopper (Empoasca kerri Pruthi)}

The incidence of aphid and leafhopper commenced in the last week of July ( $31^{\text {th }}$ SMW) and reached to peak in the second week of September $\left(37^{\text {th }}\right.$ SMW) i.e. 9.89 aphid/ three leaves and 5.12 leafhopper/ three leaves at $30.0^{\circ} \mathrm{C}$ maximum temperature, $21.0^{\circ} \mathrm{C}$ minimum temperature, 78.0 per cent relative humidity and $1.60 \mathrm{~mm}$ rainfall. Thereafter, the population started declining up to last observation ( $22^{\text {nd }}$ October) and only trace population of aphid ( $0.40 /$ three leaves) and leafhopper (0.86/ three leaves) were observed. The infestation of aphid and leafhopper on groundnut crop showed significant negative correlation $(\mathrm{r}=-0.742$ and -0.561 , respectively) with maximum temperature and significant positive correlation with relative humidity $(\mathrm{r}=0.766)$, while non-significant correlation with minimum temperature $(\mathrm{r}=0.474$ and 0.274 , respectively) and rainfall $(\mathrm{r}=0.399$ and 0.278 respectively) were observed in both the cases. These results were corroborating with Chodhary (2015) and Ahir et al., (2017) who reported that aphid population had nonsignificant negative correlation with higher 
temperature, while positively correlated with relative humidity and rainfall. Similar results for leafhopper have been reported by Nigude et al., (2018) and Sharma and Sharma (1997). The present results were partial corroborate with that of Yadav et al., (2007) and Kandakoor et al., (2012) who reported that the incidence of aphid on groundnut remains throughout the crop period with peak population in the fourth week and first week of September, respectively. They also observed that the aphid population had non- significant negative correlation with maximum temperature. Amarshibhai (2004) revealed that incidence of aphid was commenced in the last week of July (four week after sowing). The aphid population increased very fast during next week and reached at peak level in the second week of August supports the present findings. The ambient temperature and high relative humidity favored to increase the leafhopper population whereas, high temperature and heavy rainfall decreased the pest population Singh et al., (1990).

Table.1 Seasonal incidence of major sucking insect pests and their natural enemies on variety RG 382 of groundnut

\begin{tabular}{|c|c|c|c|c|c|c|c|c|c|c|}
\hline \multirow[t]{2}{*}{ S. $\mathbf{N}$. } & \multirow[t]{2}{*}{ SMW* } & \multirow[t]{2}{*}{$\begin{array}{l}\text { Date of } \\
\text { observation }\end{array}$} & \multicolumn{2}{|c|}{$\begin{array}{l}\text { Temperature } \\
\left({ }^{\circ} \mathrm{C}\right)\end{array}$} & \multirow[t]{2}{*}{$\begin{array}{l}\text { RH } \\
(\%)\end{array}$} & \multirow[t]{2}{*}{$\begin{array}{l}\text { Rainfall } \\
(\mathbf{m m})\end{array}$} & \multicolumn{2}{|c|}{$\begin{array}{l}\text { Mean population } / 3 \\
\text { leaves }\end{array}$} & \multicolumn{2}{|c|}{$\begin{array}{l}\text { Mean population } \\
\text { plants }\end{array}$} \\
\hline & & & $\operatorname{Max}$ & Min. & & & Aphid & Leafhopper & C. septum & $\begin{array}{l}\text { Maggot of } \\
\text { Syrphid spp. }\end{array}$ \\
\hline 1. & 31 & $30 / 07 / 2018$ & 34.0 & 32.2 & 62 & 24.8 & 0.82 & 1.20 & 0 & 0 \\
\hline 2. & 32 & $06 / 08 / 2018$ & 32.8 & 24.9 & 77 & 13.6 & 2.96 & 2.38 & 0.42 & 0.24 \\
\hline 3. & 33 & $13 / 08 / 2018$ & 34.4 & 24.7 & 72 & 14.6 & 4.68 & 2.00 & 1.26 & 0.86 \\
\hline 4. & 34 & $20 / 08 / 2018$ & 31.2 & 23.8 & 80 & 48.4 & 7.26 & 3.26 & 1.80 & 1.36 \\
\hline 5. & 35 & $27 / 08 / 2018$ & 31.5 & 24.0 & 77 & 34.0 & 7.82 & 3.10 & 2.14 & 1.60 \\
\hline 6. & 36 & $03 / 09 / 2018$ & 30.5 & 22.9 & 81 & 33.0 & 9.20 & 4.16 & 2.40 & 1.90 \\
\hline 7. & 37 & $10 / 09 / 2018$ & 30.0 & 21.0 & 78 & 1.6 & 9.89 & 5.12 & 2.82 & 2.20 \\
\hline 8. & 38 & $17 / 09 / 2018$ & 34.2 & 20.2 & 63 & 0.0 & 7.12 & 4.00 & 3.00 & 2.80 \\
\hline 9. & 39 & $24 / 09 / 2018$ & 32.8 & 19.1 & 64 & 19.8 & 5.42 & 3.20 & 2.20 & 2.00 \\
\hline 10. & 40 & $01 / 10 / 2018$ & 36.7 & 18.9 & 51 & 0.0 & 3.80 & 3.18 & 1.40 & 1.24 \\
\hline 11. & 41 & $08 / 10 / 2018$ & 35.7 & 15.4 & 47 & 0.0 & 2.42 & 2.40 & 0.60 & 1.00 \\
\hline 12. & 42 & $15 / 10 / 2018$ & 35.0 & 14.5 & 42 & 0.0 & 1.26 & 1.96 & 0.40 & 0.60 \\
\hline 13 & 43 & $22 / 10 / 2018$ & 34.1 & 12.8 & 43 & 0.0 & 0.40 & 0.86 & 0 & 0.20 \\
\hline
\end{tabular}

Table.2 Correlation coefficient of sucking insect pests with weather parameters and natural enemies of groundnut

\begin{tabular}{|l|c|c|c|c|c|c|}
\hline \multirow{2}{*}{ Parameter } & \multicolumn{2}{|c|}{ Temperature $\left.\mathbf{(}^{\mathbf{0}} \mathbf{C}\right)$} & $\begin{array}{l}\text { Relative } \\
\text { humidity }(\boldsymbol{\%})\end{array}$ & $\begin{array}{l}\text { Rainfall } \\
(\mathbf{m m})\end{array}$ & C. septum & $\begin{array}{c}\text { Maggot of } \\
\text { syrphid spp. }\end{array}$ \\
\cline { 2 - 7 } & Max. & Min. & $0.766^{*}$ & 0.399 & $0.931^{*}$ & $0.835^{*}$ \\
\hline Aphid & $-0.742^{*}$ & 0.474 & $0.564^{*}$ & 0.278 & $0.914^{*}$ & $0.881^{*}$ \\
\hline Leafhopper & $-0.561^{*}$ & 0.274 & $0.570^{*}$ & 0.202 & - & - \\
\hline C. septum & -0.538 & 0.308 & 0.378 & 0.049 & - & - \\
\hline $\begin{array}{l}\text { Maggot of } \\
\text { syrphid spp. }\end{array}$ & -0.390 & 0.110 & & & & \\
\hline
\end{tabular}

*Significant at $5 \%$ level 
Fig.1 Effect of weather parameters on the incidence of major sucking insect pests of groundnut

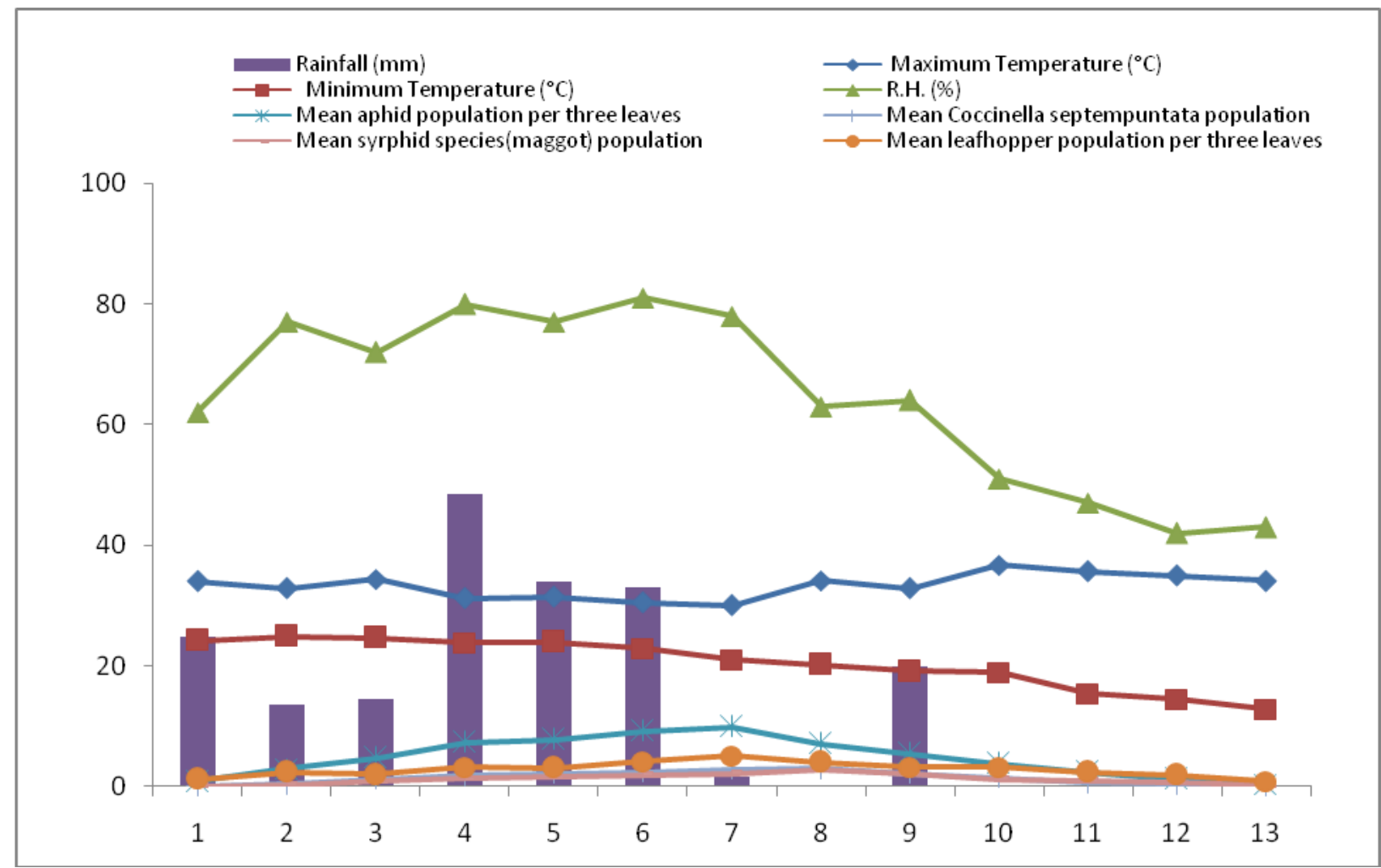

\section{Natural enemies}

The population of Lady bird beetle (Coccinella septempunctata L.) and Syrphid fly (Syrphid spp.) were appeared in the first week of August (32th SMW) and increased with the increase in aphid and leafhopper population which was maximum in the third week of September (38th SMW) i.e. 3.00 and 2.80 per five plants, respectively at $34.2^{\circ} \mathrm{C}$ maximum temperature, $20.2^{\circ} \mathrm{C}$ minimum temperature, $63 \%$ relative humidity and 0.0 $\mathrm{mm}$ rainfall. The population of both the predators were significant positively correlated with aphid $(r=0.931$ and $r=0.835)$ and leafhopper $(r=0.914$ and $r=0.881)$ population. The data of correlation also showed that both the predators had nonsignificant correlation with weather parameters however, lady bird beetle had significant positive correlation with relative humidity $(\mathrm{r}=0.570)$. The peak populations of predators were observed just next week of the peak population of sucking pests. Similar results have been observed by Srikanth and Lakkundi in 1990. They also reported highly significant positive correlation between aphid and predator populations. The results are further conformity with those of Bhede et al., 2018 who reported that population of ladybird beetle and maggot of syrphid fly showed significant positive correlation with aphid population. Jangu, 2005 partially corroborates with results who observed that the population of $C$. septempunctata was appeared in the fourth week of August and reached to maximum in the first week of September.

\section{Acknowledgements}

The author acknowledges the support from Co-author, Guide, Head of department of Entomology, Director of Research and Dean of S.K.N. College of Agriculture, S.K.N. 
Agriculture University, Jobner for their valuable suggestions and providing facilities for conducting the experiment.

\section{References}

Ahir, K.C., Saini, A. and Rana, B.S. 2017. Seasonal Incidence of Tobacco Caterpillar, Spodoptera litura Fab. Infesting Groundnut (Arachis hypogaea L.), Int. J. Pure App. Biosci. 5 (2): 267271.

Ahir, K.C., Saini, A., Rana, B.S. and Dangi, N.L. 2017. Population dynamics of sucking pests in relation to weather parameter in groundnut Arachis hypogaea L. J. Entomol. Zool. Stud, 5 (2): 960-963.

Amarshibhai, S.D. 2004. Management of sucking pests infesting groundnut under dry farming condition. M.Sc. (Ag.) thesis, submitted to Department of Entomology. JAU, Junagarh (Gujarat).

Bhede, B.V., Bhosle, B.B. and Zanwar, P.R. 2018. Correlation and regression of aphid on cauliflower with abiotic and biotic factors of environment. $J$. Entomol. Res. Soc. 42 (3): 355-359.

Choudhary, H.S. 2015. Studies on the incidence and losses caused by the insect pests in groundnut (Arachis hypogaea L.) M.Sc. (Ag.) thesis, submitted to Department of Entomology. MPUAT, Udaipur (Rajasthan).

Jangu, R.N. 2005. Biology and management of aphid, Aphis craccivora Koch on cowpea, Vigna unguiculata Linn. M.sc. (Ag.) thesis, submitted to Department of Entomology. RAU, Bikaner (Rajasthan).

Kandakoor, S.B., Khan, H.K., Gowda, G.B., Chakravarthy, A.K., Kumar, C.T.A. and Venkataravana, P. 2012. The incidence and abundance of sucking insect's pests on groundnut. Current Biotica, 6 (3): 342-348.

Mathur, R.S. and Khan, M.A. (1997). Groundnut is poor men nut. Indian Farmers Digest, 30 (5): 29-30.

Mehta, J. (2002). Phenotypic Stability in Spanish bunch groundnut, M.Sc. (Ag.) Thesis, Gujarat Agricultural University, Sardarkrushinagar, GUJARAT (INDIA).

Mer, A.N., Parmar, G.M., Vikani, R.M. and Kelaiya, D.S. (2016). Effect of climatic factors on incidence of jassid, Empoasca kerri (Pruthi) infesting groundnut. Internat. J. Plant Protec., 9(2): 608-610.

Nandagopal, V. (1992). Studies on integrated pest management in Groundnut in Saurashtra, Ph.D. Thesis, Saurashtra University, Rajkot, GUJARAT (INDIA).

Nigude, V.K., Patil, S.P., Patil, S.A. and Bagade, A.S. 2018. Management of sucking pests of groundnut with newer molecules of insecticides Arachis hypogaea L. Int. J. Curr. Microbiol. App. Sci, 7 (1): 566-569.

Satpatty, J.M. 1973. Field tests with granulated insecticides for the control of Leucinodes orbonalis Guen. (Lepidoptera: Pyralidae) on brinjal. J. AGR. SCI, 43: 1081-1986.

Sharma, G. M. and Sharma, P. D. 1997. Population dynamics of cotton leaf hopper Amrasca biguttula biguttula (Ishida) on cotton and okra in relation to the physical factors of environment in Haryana. Annals of Biology, 13: 179183.

Singh, T.V.K., Singh, K.M. and Singh, R.N. 1990. Groudnut pest complex: III. Incidence of insect pests in relation to agroclimatic condition as determined by graphical super imposition technique. Indian J Entomol, 52 (4): 686-692. 
Srikanth, J. and Lakkundi, N.H. 1990. Seasonal population fluctuation of cowpea aphid, Aphis craccivora Koch and its predatory coccinellid. Int J Trop Insect Sci, 11 (1): 21-26.
Yadav, J.B., Singh, R.S. and Tripathi, R.A. 2007. Effect of weather parameters on pest complex of okra. Annals of Plant Protection Science, 15: 477-478.

\section{How to cite this article:}

Sunil Gocher and Sarfraz Ahmad. 2019. Seasonal Incidence of Major Sucking Insect Pests of Groundnut in Relation to Weather Parameters of Semi-Arid Region of India. Int.J.Curr.Microbiol.App.Sci. 8(08): 1106-1111. doi: https://doi.org/10.20546/ijcmas.2019.808.129 